\title{
Karakteristik Sosial Demografi dan Faktor Pendorong Peningkatan Kinerja Kader Posyandu
}

\section{Social Demography Characteristics and Driven Factors in Improving Performance of Cadre of Integrated Services Centre (Posyandu)}

\author{
Megawati Simanjuntak ${ }^{1}$ \\ ${ }^{1}$ Departemen Ilmu Keluarga dan Konsumen, \\ Fakultas Ekologi Manusia, Institut Pertanian Bogor, Bogor
}

\begin{abstract}
Posyandu is one of the community participation approach in health sector that is managed by cadres, with the main problem arises is the declining number of visits of mothers of infants and toddlers. The aimed of this research were to analyze the level of performance of posyandu cadres, and to analyze the factors that influence performance. Research conducted in Ciherang Village with 30 samples that was selected using random sampling. Most of the cadres including productive age, junior secondary education, medium families size, and has been married to a third have children under five. The average of job length was 9 years old, had attended training related to posyandu, a cadre motivation is the desire to help the community. Average cadre incentives was Rp20,000 per person per month with the support of family and community leaders. The result showed that most of cadre's performance can be categorized high. The higher the incentives received by the cadres and the more participation of cadres in training at least once influenced significantly for the improving of cadre's performance.
\end{abstract}

Keywords: cadre, demography, performance, posyandu, social

\section{Abstrak}

Posyandu merupakan salah satu bentuk pendekatan partisipasi masyarakat di bidang kesehatan yang dikelola oleh kader posyandu dengan masalah utama adalah penurunan jumlah kunjungan ibu-ibu bayi dan balita ke posyandu. Penelitian ini bertujuan untuk menganalisis tingkat kinerja kader posyandu dan pengaruh karakteristik sosial demografi dan faktor pendorong mempengaruhi kinerja kader posyandu. Penelitian dilakukan di Desa Ciherang dengan jumlah sampel sebanyak 30 kader posyandu yang ditentukan secara acak. Sebagian besar kader posyandu termasuk kategori usia produktif, pendidikan SLTP, besar keluarga tergolong keluarga sedang dengan rata-rata 5 orang, dan telah menikah dengan sepertiganya mempunyai balita. Rata-rata lama menjadi kader adalah 9 tahun, pernah mengikuti pelatihan yang terkait dengan posyandu, motivasi menjadi kader adalah keinginan untuk menolong masyarakat. Rata-rata kader memperoleh insentif $\mathrm{Rp} 20.000$ per orang per bulan dengan adanya dukungan dari keluarga dan tokoh masyarakat. Kinerja kader posyandu tergolong baik, artinya kader mampu melaksanakan tugas dan tanggung jawabnya dengan baik. Semakin tinggi insentif yang diterima oleh kader dan pernah tidaknya kader mengikuti pelatihan memberikan pengaruh dalam meningkatkan kinerja kader posyandu.

Kata Kunci: kader, demografi, kinerja, posyandu, sosial

\section{Pendahuluan}

Posyandu merupakan salah satu bentuk pendekatan partisipasimasyarakat dibidangkesehatanyang dikelola oleh kader posyandu yang telah mendapatkan pendidikan dan pelatihan dari puskesmas. Kader posyandu mempunyai peran yang cukup penting karena merupakan sosok pelayan kesehatan (health provider) yang berada dekat dengan kegiatan sasaran posyandu dan memiliki frekuensi tatap muka kader yang lebih sering daripada petugas kesehatan lainnya. Tugas utama kader posyandu dalam kegiatan KIA (Kesehatan Ibu dan Anak) di posyandu adalah melakukan pendaftaran, penimbangan serta pengukuran, mencatat pelayanan ibu dan anak dalam buku KIA, menggunakan buku KIA sebagai bahan penyuluhan, dan melaporkan penggunaan buku KIA kepada petugas kesehatan (Heru, 2005).

Menurut Mangkunegara (2000) hal yang sangat penting selain program yang diselenggarakan posyandu, kinerja petugas posyandu juga sangat perlu untuk ditingkatkan. Kinerja adalah hasil kerja secara kualitas dan kuantitas yang dicapai oleh seseorang pegawai dalam melaksanakan tugasnya sesuai dengan tanggung jawab yang diberikan kepadanya. Dalam hal ini, seorang petugas posyandu berperan besar untuk meningkatkan kinerja secara optimal.

Desa Ciherang merupakan salah satu desa di Kecamatan Dramaga dengan jumlah posyandu 


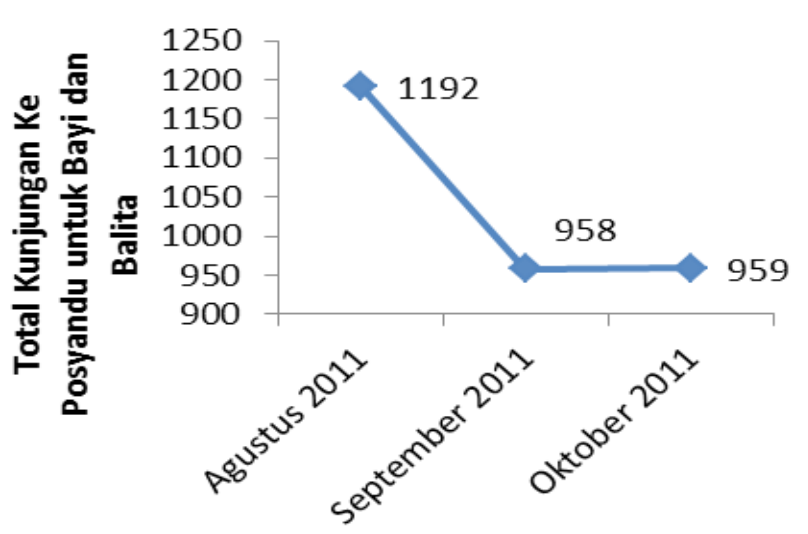

Gambar 1 Penurunan kunjungan ke posyandu dari ibu yang memiliki bayi dan balita

(Sumber: Laporan Puskesmas UPT Dramaga)

sebanyak 15 buah dan kader sebanyak 81 orang yang tersebar di 11 RW. Hasil wawancara dengan bidan desa dan pihak puskesmas menunjukkan ada indikasi penurunan jumlah kunjungan ibu-ibu bayi dan balita ke posyandu (Gambar 1). Terjadinya penurunan kunjungan ke posyandu dapat mengindikasikan kecenderungan masyarakat menggunakan layanan kesehatan hanya saat membutuhkan misalnya saat mereka sakit, bukan untuk mendapatkan layanan monitoring atau meningkatkan pengetahuan kesehatan dan gizi seperti yang diberikan di posyandu. Pergeseran kebutuhan menjadi penyebab posyandu semakin ditinggalkan. Semakin banyak ibuibu yang membawa balitanya ke fasilitas kesehatan atau praktik dokter swasta untuk imunisasi. Disamping itu, hasil wawancara dengan bidan setempat ternyata juga mengindikasikan ada beberapa kader yang tidak aktif lagi di posyandu karena kesibukan dalam kegiatan lain di luar kegiatan posyandu.

Menurut K-STATE (2006), penilaian kinerja adalah proses yang penting untuk meningkatkan efektivitas penyuluh. Kualitas kerja dan produktivitas kinerja penyuluh didefinisikan oleh delapan elemen yang terdiri dari kualitas pekerjaan, ketergantungan, jadwal kerja, kebiasaan kerja, alokasi kerja, ketenangan, organisasi kerja, dan kepuasan pelanggan. Menurut Vijayaragavan dan Singh (1997) dalam Thach, Ismail, Uli dan Idris (2007) kinerja adalah proses mengevaluasi karyawan dalam melakukan tugas yang diberikan dalam rangka membimbing dan mengembangkan potensi karyawan. Menurut Terry dan Israel (2004), kinerja karyawan adalah kunci keberhasilan organisasi dan harus dievaluasi. Dalam kaitannya dengan kinerja, Terry dan Israel (2004) menunjukkan bahwa penyuluh harus mengembangkan dan memelihara keterampilan dalam menilai dan menanggapi kebutuhan klien, yang dapat memastikan bahwa klien menerima informasi terkini dan akurat.

Menurut Mangkunegara (2000), kinerja (prestasi kerja) adalah hasil kerja secara kualitas dan kuantitas yang dicapai oleh seseorang pegawai dalam melaksanakan tugasnya sesuai dengan tanggung jawab yang diberikan kepadanya. Selanjutnya menurut Cushway (2002) kinerja adalah menilai bagaimana seseorang telah bekerja dibandingkan dengan target yang telah ditentukan. Rivai (2004) mengemukakan kinerja merupakan perilaku yang nyata yang ditampilkan setiap orang sebagai prestasi kerja yang dihasilkan oleh karyawan sesuai dengan perannya dalam perusahaan. Terakhir Mathis dan Jackson (2002) menyatakan bahwa kinerja pada dasarnya adalah apa yang dilakukan atau tidak dilakukan karyawan. Berdasarkan konsep kinerja penyuluh yang telah dirangkum ahli, jika dikaitkan dengan penelitian yang akan dilakukan, maka konsep yang dibangun tentang kinerja adalah hasil kerja secara kualitas dan kuantitas yang dicapai oleh seseorang kader dalam melaksanakan tugasnya sesuai dengan tanggung jawab yang diberikan kepadanya.

Hasil studi Thach, Ismail, Uli dan Idris (2007) mengungkapkan empat faktor individu yang secara signifikan memberikan kontribusi terhadap kinerja penyuluh, yaitu,keterampilan sosial, keterampilan pelaksanaan program, motivasi, dan keterampilan perencanaan program.

Selanjutnya hasil studi Suhanda, Jahi, Sugihen, dan Susanto (2008) mengindikasikan bahwa perbedaan kelembagaan penyelenggara penyuluhan pada tingkat pemerintahan wilayah lokal serta perbedaan komoditas dominan di wilayah kerja penyuluh turut memberikan kontribusi terhadap perwujudan kinerja penyuluh pertanian. Studi lainnya oleh Fabusoro, Awotunde, Sodiya, dan Alarima (2008) menunjukkan bahwa kinerja penyuluh tergolong rendah. Dari 14 faktor yang diteliti, interaksi bos dan bawahan adalah satusatunya faktor yang mempengaruhi kinerja. Tidak ada pengaruh signifikan faktor personal terhadap kinerja penyuluh. Selanjutnya hasil studi Long dan Swortzel (2007) menunjukkan bahwa kinerja sebagian besar penyuluh adalah tinggi dengan faktor posisi penyuluh mempengaruhi secara nyata kinerja penyuluh.

Studi sebelumnya telah menunjukkan bahwa kinerja tergantung pada banyak faktor. Berdasarkan literatur, untuk tampil baik dalam pekerjaan penyuluhan, penyuluh harus memiliki unsur-unsur berikut: motivasi, pengetahuan teknis dan keterampilan, keterampilan metode 
penyuluhan, program pengembangan keterampilan, keterampilan sosial, dan kemampuan kontak eksternal. McCaslin dan Mwangi (1994) menunjukkan bahwa karyawan yang bekerja lebih keras akan berperforma lebih baik jika mereka termotivasi dan puas dengan pekerjaan mereka. Selain itu, sulit bagi penyuluh untuk melayani klien mereka dengan baik tanpa insentif yang memadai. Selain itu, Lindner dan Dooley (2002) menyatakan bahwa kinerja yang efektif membutuhkan pengetahuan dan membantu membuat kemungkinan akuisisi pengetahuan baru. Penyuluh juga memerlukan kompetensi dalam perencanaan program dan pengem-bangan (Boyd, 2004). The Texas A and MUniversity System(2005) menyatakan bahwa keterampilan sosial penyuluh seperti dalam menjalin hubungan kerja yang efektif dengan rekan kerja, kolega, supervisor, relawan, klien, tokoh masyarakat adalah kunci penting dalam menentukan kinerja. Akhirnya, Van den Ban dan Hawkins (1988) mencatat bahwa kemampuan kontak eksternal agen penyuluh secara signifikan mempengaruhi hasil yang diinginkan dan efektivitas penyuluhan.

Hasil studi Rohmani (2001) mengindikasikan bahwa faktor internal dan ekstemal penyuluh yang berpengaruh sangat nyata terhadap kinerja penyuluh pertanian dalam pelaksanaan tugas pokoknya adalah: jenjang jabatan fungsional, usia, golongan, masa kerja penyuluh, dan komoditas dominan di wilayah binaan. Studi Vitriah (2010) menunjukkan adanya hubungan signifikan pendidikan dan motivasi dengan kinerja kader posyandu. Tidak terdapat hubungan usia dan pekerjaan dengan kinerja kader posyandu. Hasil uji regresi linear berganda menunjukkan variabel pendidikan dan variabel motivasi merupakan variabel paling berhubungan dengan kinerja kader posyandu.

Hasil penelitian Mastuti (2003) menunjukkan bahwa ada hubungan jenjang pelatihan, proses pemilihan menjadi kader dan keikutsertaan kader dalam organisasi lain dengan kelangsungan kader. Tidak ada hubungan usia dengan kelangsungan kader, tidak ada hubungan pendidikan dengan kelangsungan kader, tidak ada hubungan keinginan terhadap insentif dengan kelangsungan kader posyandu.

Fenomena di atas mendorong dilaksanakannya penelitian ini dengan tujuan untuk melihat bagaimana kinerja kader posyandu. Asumsi yang digunakan dalam penelitian ini adalah kinerja kader yang semakin baik akan mendorong kunjungan para ibu ke posyandu. Hal ini sejalan dengan penelitian Puspasari (2002) bahwa terdapat hubungan positif sangat nyata antara kinerja kader dengan keberhasilan posyandu, pada akhirnya keberhasilan posyandu akan mendorong peningkatan kunjungan sasaran. Disisi lain, faktor sosial demografi dan faktor pendorong kinerja posyandu dapat mempengaruhi kinerja kader. Penelitian ini dibatasi hanya mengkaji kinerja kader dari sudut pandang kader, tanpa melihat dari sudut pandang klien. Adapun fokus penelitian ini adalah menganalisis kinerja kader posyandu. Penelitian ini bertujuan untuk (1) Mengidentifikasi karakteristik sosial demografi dan faktor pendorong kinerja posyandu; (2) Menganalisis tingkat kinerja kader posyandu; dan (3) Menganalisis pengaruh karakteristik sosial demografi dan faktor pendorong mempenga-ruhi kinerja kader posyandu.

\section{Metode Penelitian}

Populasi penelitian ini adalah seluruh kader posyandu yang ada di Desa Ciherang, yakni sebanyak 81 orang yang berasal dari 15 posyandu yang tersebar di 11 RW. Sampel ditentukan secara acak dengan jumlah sampel sebanyak 30 kader posyandu yang tersebar di Desa Ciherang.

Penelitian ini berbentuk explanatory research dengan disain penelitian studi kuantitatif menggunakan metode survey. Dalam penelitian ini terdapat dua peubah, yakni peubah bebas dan peubah terikat. Peubah bebas terdiri atas karakteristik sosial demografi (X1) dan faktor pendorong (X2), sedangkan peubah terikat adalah kinerja kader posyandu (Y1). Karakteristik sosial demografi kader terdiri dari: usia (X11), jumlah anggota keluarga (X12), tingkat pendidikan (X13), status perkawinan (X14), adanya anak balita (X15), status pekerjaan (X16), dan lama menjadi kader (X17). Faktor pendorong mencakup : motivasi menjadi kader (X21), insentif yang diterima (X22), pelatihan yang pernah diikuti (X23), dukungan keluarga (X24) dan dukungan tokoh masyarakat (X25). Kinerja kader posyandu mencakup tiga dimensi yakni tugas persiapan (Y11), pelaksanaan (Y12), dan tugas evaluasi (Y13).

Dalam penelitian ini kinerja kader diukur berdasarkan uraian tugasnya di posyandu. Tugas kader terdiri dari 3 (tiga) kelompok yaitu tugas persiapan sebelum hari $\mathrm{H}$ posyandu, kegiatan utama pada hari $\mathrm{H}$ posyandu dan kegiatan setelah hari $\mathrm{H}$ posyandu. Keseluruhannya terdapat 23 pertanyaan dan masingmasing diberi nilai 4 jika sangat baik, 3 jika baik, 2 jika kurang baik dan 1 jika sangat tidak baik sehingga diperoleh skor maksimum dari semua pertanyaan adalah 60. Selanjutnya, kinerja kader dikategorikan 
menjadi 2 kelompok, yaitu baik apabila total skor $60 \%$ ke atas dan dikategorikan tidak baik apabila total skor $<60 \%$.

Nilai validitas kinerja kader posyandu berkisar antara 0,315 hingga 0,818 , sedangkan nilai reliabilitas sebesar 0,933, artinya instrumen yang digunakan termasuk sangat reliable. Pengolahan data dibagi menjadi dua, yakni statistika deskriptif dan statistika induktif (inferensia). Analisis korelasi Spearman dan Kendal Tau-B digunakan untuk menganalisis hubungan antar peubah. Analisis regresi berganda digunakan untuk mengetahui faktor-faktor yang mempengaruhi kinerja kader posyandu.

\section{Hasil dan Pembahasan}

\section{Karakteristik Sosial Demografi Kader Posyandu}

Kegiatan posyandu sangat tergantung pada kader posyandu, keberadaan kader posyandu dibutuhkan sebagai salah satu sistem penyelenggaraan pelayanan kebutuhan kesehatan dasar. Kader posyandu merupakan ujung tombak pelayanan kesehatan yang merupakan kepanjangan tangan puskesmas. Dalam penelitian ini hampir dua pertiga kader yang menjadi contoh berusia di atas 35 tahun dengan rataan 41,87+10,71 tahun. Artinya rata-rata contoh adalah masuk kategori usia produktif (Tabel 1).

Dalam rentang usia produktif kader posyandu dapat lebih mengalokasikan waktunya untuk aktif dalam kegiatan posyandu. Menurut Havigurst dan Robert (1972) usia kader adalah termasuk dewasa madya (usia pertengahan antara 30-60 tahun) dengan tugas pengembangan pada usia ini adalah mengembangkan kegiatan mengisi waktu senggang untuk orang dewasa dengan adanya perubahan minat dalam tanggungjawab warga negara dan sosial serta mengembangkan niat pada waktu luang yang berorientasi pada kedewasaan dan pada tempat kegiatan yang berorientasi pada keluarga.

Berdasarkan Tabel 1 terlihat bahwa tingkat pendidikan setengah contoh adalah tamat SLTP dan SLTA dengan rata-rata lama pendidikan $8,63+3,65$ tahun. Hal ini berarti tingkat pendidikan contoh secara umum adalah masuk kategori pendidikan dasar. Kemampuan ini sejalan pula dengan salah satu dari tujuh kriteria yang harus dipenuhi oleh seorang kader seperti tercantum dalam Instruksi Menteri Dalam Negeri No. 9 Tahun 1990 tentang peningkatan pembinaan mutu Pos
Pelayanan Terpadu (Posyandu), yaitu dapat membaca dan menulis (Tabel 1).

Besar keluarga adalah jumlah seluruh anggota keluarga yang tinggal bersama dalam satu rumah. Besar keluarga menurut BKKBN (1998), dikategorikan menjadi tiga kelompok yaitu kecil ( $\leq 4$ orang), sedang (5-7 orang) dan besar ( $>7$ orang). Jumlah keluarga yang besar dapat berimplikasi pada semakin banyak waktu yang dialokasikan untuk kegiatan posyandu jika anggota keluarga lainnya termasuk usia produktif, berbeda jika jumlah anggota keluarga yang dimiliki besar adalah dikarenakan jumlah anak balita yang memerlukan perhatian lebih banyak dari ibu sehingga waktu untuk kegiatan posyandu akan semakin sedikit (Tabel 1). Rata-rata jumlah anggota keluarga adalah $5,47+2,76$ dengan kisaran antara 2 orang hingga 11 orang anggota dalam satu rumah tangga. Terakhir, lebih dari setengah contoh memiliki pekerjaan tetap selain sebagai kader. Adanya pekerjaan lain tentu akan membuat kader posyandu harus mampu mengalokasikan waktu sebaik mungkin untuk kegiatan posyandu dan pekerjaannya.

Sebagian besar kader telah menikah dan sekitar sepertiganya mempunyai balita, dengan jumlah balita adalah satu anak. Keberadaan balita merupakan tanggung jawab keluarga yang harus dilakukan kader. Hasil studi Benham et al. (2010) mengindikasikan keseimbangan antara pekerjaan dan keluarga berpengaruh terhadap kinerja. Jika ada balita yang harus diasuh oleh kader maka waktunya akan semakin banyak tersita untuk kegiatan pengasuhan dan semakin sedikit untuk kegiatan posyandu (Tabel 1). Rata-rata contoh menjadi kader adalah 9 tahun dengan kisaran antara 0,08 hingga 26 tahun. Data ini menunjukkan bahwa kader sudah cukup berpengalaman dalam mengelola posyandu yang mengindikasikan adanya dukungan dari keluarga contoh menjadi kader (Tabel 1).

\section{Faktor-Faktor Pendorong Kinerja Kader Posyandu}

Lebih dari separuh motivasi menjadi kader posyandu dari responden adalah keinginan untuk menolong masyarakat. Hal ini sejalan dengan salah satu dari tujuh kriteria yang harus dipenuhi oleh seorang kader posyandu seperti tercantum dalam Instruksi Menteri Dalam Negeri No. 9 tahun 1990 tentang peningkatan pembinaan mutu Pos Pelayanan Terpadu (Posyandu), yakni: (1) dapat membaca dan 
Tabel 1 Sebaran Karakteristik Sosial Demografi Kader Posyandu

\begin{tabular}{|c|c|}
\hline Peubah & $\begin{array}{c}\text { Persen } \\
(\%)\end{array}$ \\
\hline \multicolumn{2}{|l|}{ Usia kader (tahun) } \\
\hline$<25$ tahun & 0,0 \\
\hline 25 - 35 tahun & 30,0 \\
\hline$>35$ tahun & 70,0 \\
\hline \multicolumn{2}{|l|}{ Tingkat pendidikan kader } \\
\hline Tidak Sekolah & 3,3 \\
\hline Tidak Tamat SD & 3,3 \\
\hline Tamat SD & 36,7 \\
\hline Tamat SLTP & 20,0 \\
\hline Tamat SLTA & 30,0 \\
\hline Diploma/Sarjana & 6,7 \\
\hline \multicolumn{2}{|l|}{ Satus perkawinan } \\
\hline Belum Menikah & 3,3 \\
\hline Menikah & 93,3 \\
\hline Janda & 3,3 \\
\hline \multicolumn{2}{|c|}{ Ada anak balita yang harus diasuh oleh kader } \\
\hline Tidak mempunyai balita & 70,0 \\
\hline Mempunyai balita & 30,0 \\
\hline \multicolumn{2}{|l|}{ Jumlah Anggota Keluarga } \\
\hline$\leq 4$ orang & 46,7 \\
\hline $5-6$ orang & 23,3 \\
\hline$\geq 7$ orang & 30,0 \\
\hline \multicolumn{2}{|l|}{ Status Pekerjaan } \\
\hline Bekerja & 43,3 \\
\hline Tidak bekerja & 56,7 \\
\hline \multicolumn{2}{|l|}{ Lama menjadi kader } \\
\hline$<5$ tahun & 40,0 \\
\hline $5-10$ tahun & 20,0 \\
\hline$>10$ tahun & 40,0 \\
\hline
\end{tabular}

menulis; (2) berjiwa sosial dan mau bekerja sama secara sukarela; (3) mengetahui adat istiadat serta kebiasaan masyarakat setempat; (4) mempunyai waktu luang yang cukup; (5) bertempat tinggal di wilayah posyandu; (6) berpenampilan ramah dan simpatik; serta (7) diterima masyarakat setempat (Tabel 2). Hasil studi dari Thach, Ismail, Uli dan Idris (2007) serta Vitriah (2010) mengungkapkan salah satu faktor individu yang secara signifikan memberikan kontribusi terhadap kinerja penyuluh adalah motivasi. Namun dalam penelitian ini tidak ditemukan hubungan yang signifikan antara keduanya.

Seluruh kader memperoleh insentif yang besarnya berbeda-beda antar kader (Tabel2). Kisarannya adalah antara Rp 6.666 hingga Rp 100.000 per orang per bulan, namun yang paling banyak adalah sebesar Rp 20.000 per orang per bulan. Meskipun pekerjaan kader adalah sebagai relawan atau bersifat filantropi namun para kader masih mengharapkan adanya insentif yang lebih memadai. Jumlah yang diterima selama ini dianggap kurang memadai oleh sebagian besar kader sehingga diusulkan agar besarnya insentif dapat dinaikkan menjadi Rp 300.000 per orang per bulan oleh sekitar dua per tiga kader dan sisanya menyarankan insentif sebesar Rp 100.000 per orang per bulan. Hasil wawancara mendalam juga mengindikasikan insentif yang diterima masih sangat kurang dibandingkan dengan banyak-nya kerja yang dilakukan. 
Tabel 2 Korelasi antar Peubah Penelitian

\begin{tabular}{lc}
\hline \multicolumn{1}{c}{ Peubah } & $\begin{array}{c}\text { Kinerja kader } \\
\text { (skor) }\end{array}$ \\
\hline Usia (tahun) & 0,208 \\
Tingkat pendidikan (tahun) & 0,085 \\
Jumlah Anggota (orang) & 0,219 \\
Lama menjadi kader (tahun) & $\mathbf{0 , 3 7 5}$ \\
Besar insentif (rupiah/bulan) & 0,278 \\
\hline
\end{tabular}

Keterangan : $\quad *$ Nyata pada $\mathrm{p}<0,05$;

** Nyata pada $\mathrm{p}<0,01$

Para kader berharap meskipun perannya sebagai tenaga sukarela, namun dapat memperoleh penghargaan yang lebih layak. Penghargaan atau reward ini sangat penting untuk menunjang peningkatan kinerja. Sama halnya dengan petugas posyandu yang sebagian besar adalahkader sukarela darimasyarakat, sangatmemerlukan penghargaan atas pekerjaan yang sudah dilakukan. Kader mungkin tidak mengharapkan penghargaan dalam bentuk gaji yang besar, karena kader bekerja dengan sukarela.

Hasil temuan penelitian ini sejalan dengan temuan Oloruntoba dan Ajayi (2003) yang menyatakan bahwa hanya $10 \%$ responden yang sangat puas dengan sistem reward yang berlaku. Sementara responden yang tidak puas sebesar dengan sistem reward adalah $58,9 \%$, yang merupakan indikasi bahwa para karyawan umumnya tidak puas dan dapat mempengaruhi produktifitasnya seperti dinyatakan oleh Odugbesan (1985), Greson and Livesey (1986). Meskipun demikian, hasil studi Mastuti (2003) menunjukkan bahwa tidak ada hubungan keinginan terhadap insentif dengan kelangsungan kader Posyandu.

Sebagian besar kader menyatakan pernah mengikuti pelatihan yang terkait dengan posyandu. Adapun jenis pelatihan yang pernah diikuti adalah pelatihan gizi, KB, imunisasi, kesehatan lingkungan, PIN (Pekan Imunisasi Nasional), keorganisasian, kesehatan, lansia, dan Perilaku Hidup Bersih dan Sehat (PHBS). Semua kader yang pernah mengikuti pelatihan menyatakan memperoleh manfaat dari pelatihan tersebut (Tabel 2). Lindner dan Dooley (2002) menyatakan bahwa kinerja yang efektif membutuhkan pengetahuan dan membantu membuat kemungkinan akuisisi pengetahuan baru, dimana pengetahuan ini dapat diperoleh melalui pelatihan-pelatihan.

Terkait dengan dukungan dari tokoh masyarakatdan keluarga, sebagian besar kader menyatakan ada dukungan yang diberikan oleh tokoh masyarakat dan dukungan tersebut juga berguna bagi keberlangsungan posyandu Adapun bentuk dukungan dari tokoh masyarakat yang diberikan adalah bantuan makanan untuk kader dan biaya tambahan untuk membeli PMT (Pemberian Makanan Tambahan), bantuan tenaga, berkunjung, memotivasi, dan membantu menginformasikan posyandu. Dukungan sangat diperlukan oleh kader untuk meningkatkan motivasi kerja agar tercapainya peningkatan kinerja menjadi lebih baik, mengingat bahwa kader melaksanakan tugasnya dengan sukarela. Dukungan ini sangat diperlukan oleh kader untuk meningkatkan motivasi kerja agar tercapainya peningkatan kinerja menjadi lebih baik, mengingat bahwa kader melaksanakan tugasnya dengan sukarela. Dukungan tokoh masyarakat dapat meningkatkan kepercayaan diri kader dalam melaksanakan tugas-tugasnya. Dukungan tidak hanya bersifat materil tetapi juga dalam bentuk moril sehingga jika kader menemukan hambatan dalam pekerjaannya dapat melibatkan tokoh masyarakat dalam mengatasi hambatan tersebut (Puspasari, 2002). Namun demikian, hasil analisis korelasi tidak menunjukkan hubungan yang nyata antara dukungan keluarga dan tokoh masyarakat dengan kinerja kader posyandu.

\section{Tingkat Kinerja Kader Posyandu}



Gambar 2 Kategori tingkat kinerja kader posyandu 




Keterangan: $*=$ nyata pada taraf 5\%

Gambar 3 Faktor-faktor yang berpengaruh terhadap kinerja kader posyandu

Pada Gambar 2 disajikan kategori tingkat kinerja kader dalam pelaksanaan posyandu. Sebagian besar kader merasakan kinerja posyandu yang telah dilakukannya sudah terkategori baik. Semua item yang menyusun peubah kinerja umumnya adalah baik dan sangat baik. Dengan demikian, jika dihubungkan dengan permasalahan penelitian ini yakni semakin rendahnya tingkat kunjungan ibu-ibu, tidak sejalan dengan kinerja yang dirasakan oleh kader yang merasa puas dengan kinerjanya. Hasil penelitian ini sejalan dengan studi Long dan Swortzel (2007) yang menyatakan bahwa sebagian besar penyuluh merasa kinerjanya sudah baik. Hasil studi Aidha (2010) juga menemukan bahwa kinerja kader posyandu juga tergolong sudah baik. Namun temuan penelitian ini berbeda dengan temuan Fabusoro, Awotunde, Sodiya dan Alarima (2008) yang menyatakan bahwa kinerja penyuluh secara umum adalah rendah.

\section{Hubungan Antar Peubah}

Hasil analisis korelasi mengindikasikan adanya hubungan antara lama menjadi kader dengan kinerja kader (Tabel 3). Semakin lama menjadi kader, kinerjanya cenderung semakin tinggi. Hal ini sejalan dengan penelitian Long dan Swortzel (2007) dan Rohmani (2001) dimana terdapat hubungan positif antara kinerja dengan lama bekerja. Tidak ada hubungan yang nyata antara karakteristik internal kader posyandu dengan kinerja. Hasil ini sejalan dengan temuan Vitriah (2010) yang menyatakan tidak terdapat hubungan usia dan pekerjaan dengan kinerja kader posyandu. Mastuti (2003) juga menemukan bahwa tidak ada hubungan usia, dan pendidikan dengan kelangsungan kader. Hal ini berbeda dengan penelitian Long dan Swortzel (2007) dimana terdapat hubungan positif antara kinerja dengan usia.

\section{Faktor-Faktor yang Mempengaruhi Kinerja Kader Posyandu}

Untuk menganalisis faktor-faktor yang mempengaruhi kinerja kader posyandu digunakan metode analisis regresi liner berganda Backward (Gambar 3). Dari 10 model yang dihasilkan, dipilih model yang ke delapan, dengan pertimbangan ada 2 peubah yang memiliki pengaruh yang signifikan dan besarnya pengaruh adjusted $\mathrm{R}$ square, yakni besar insentif dan pernah tidaknya kader mengikuti pelatihan kader. Hasil penelitian ini sejalan dengan studi Mc Caslin dan Mwangi (1994) yang menyatakan bahwa insentif bekerja berpengaruh terhadap kinerja. Namun temuan ini berbeda dengan hasil penelitian Mastuti (2003) yang menunjukkan bahwa tidak ada hubungan keinginan terhadap insentif dengan kelangsungan kader Posyandu. Temuan penelitian ini juga sejalan dengan studi Lindner dan Dooley (2002) yang menyatakan bahwa kinerja yang efektif membutuhkan pengetahuan dan membantu membuat kemungkinan akuisisi pengetahuan baru.

Pada model kedelapan, koefisien $\mathrm{R}$ kuadrat (koefisien determinasi) dari faktor-faktor jumlah anggota 
keluarga, status kerja, insentif dan pernah tidaknya mengikuti pelatihan adalah 0,245 atau $24,5 \%$. Artinya, besarnya pengaruh langsung faktor-faktor tersebut secara bersama-sama terhadap kinerja kader posyandu adalah sebesar 0,245 atau 24,5\%. Adapun sisanya, yaitu $75,5 \%$ dijelaskan oleh faktor-faktor lain di luar model. Persamaan regresi bergandanya adalah : Y1 = $73,053+0,964 \times 12+4,406$ X16 + 0,000 X21 - 14,572 $\mathrm{X} 22$.

Faktor-faktor yang berpengaruh dan besarnya pengaruh secara sendiri-sendiri (parsial) terhadap kinerja kader posyandu dilihat dari koefisien Beta (koefisien regresi yang sudah distandardisasi), disajikan pada Gambar 3. Temuan penelitian ini memberikan implikasi bahwa kinerja kader posyandu dapat diperbaiki dengan meningkatkan insentif dan memperbanyak pelatihan untuk kader. Maksud diadakannya pelatihan yaitu untuk meningkatkan keterampilan dan kemampuan kerja seseorang atau sekelompok orang. Biasanya sasarannya adalah seseorang atau sekelompok orang yang sudah bekerja pada suatu organisasi yang efisien, efektivitas dan produktivitas kerjanya dirasakan perlu ditingkatkan secara terarah dan programatik (Syafrida, 2003). Karakteristik internal kader posyandu seperti jumlah anggota keluarga, tingkat pendidikan formal, usia, lama menjadi kader tidak berpengaruh signifikan terhadap kinerja kader posyandu. Artinya, karakteristik kader belum berperan terhadap kinerja atau sebaliknya kinerja kader belum memperhatikan karakteristik kader. Hasil temuan penelitian ini sejalan dengan studi Puspasari (2002) dan Sahrul (2006) dimana tidak terdapat hubungan antara status perkawinan dan status pekerjaan dengan kinerja kader.

\section{Kesimpulan}

Sebagian besar kader posyandu termasuk kategori usia produktif, pendidikan SLTP, besar keluarga tergolong keluarga sedang dengan ratarata 5 orang, dan telah menikah dengan sepertiganya mempunyai balita. Rata-rata lama menjadi kader adalah 9 tahun, pernah mengikuti pelatihan yang terkait dengan posyandu, motivasi menjadi kader adalah keinginan untuk menolong masyarakat. Ratarata kader memperoleh insentif Rp 20.000 per orang per bulan dengan adanya dukungan dari keluarga dan tokoh masyarakat.

Kinerja kader posyandu tergolong baik, artinya kader mampu melaksanakan tugas dan tanggung jawabnya dengan baik. Semakin tinggi insentif yang diterima oleh kader dan pernah tidaknya kader mengikuti pelatihan memberikan pengaruh dalam meningkatkan kinerja kader posyandu.

Dalam upaya mempertahankan bahkan meningkatkan kinerja kader posyandu perlu dipertimbangkan pemberian insentif yang lebih layak. Insentif dapat diusahakan dari iuran para ibu yang berkunjung ke posyandu atau dengan mengalokasikan dari kas desa. Partisipasi kader dalam pelatihan juga perlu ditingkatkan untuk lebih membekali para kader dengan keterampilan pengelolaan posyandu.

\section{Daftar Pustaka}

Aidha Z. 2010. Kinerja Petugas Posyandu dan Kepuasan Ibu Pengguna Posyandu Di Desa Sei Semayang Kabupaten Deli Serdang. [Internet]. [dapat diunduh dari: http://repository.usu.ac.id].

Benham-Deal TB, Jenkins JM, Deal LO, Byra A. 2010. The impact of professional development to infuse health and reading in elementary schools. American Journal of Health Education, 41(3), 155-166.

[BKKBN] Badan Koordinasi Keluarga Beren-cana Nasional. 1998. Undang-Undang RINo.10 tahun 1992 tentang Perkembangan Kependudukan dan Pembangunan Keluarga Sejahtera. Jakarta (ID): Badan Koordinasi Keluarga Berencana Nasional.

Boyd BL. 2004. Extension Agents as Admi-nistrators of Volunteers: Competencies Needed for the Future. Journal of Extension. 42(2). [Internet]. [dapat diunduh dari: http://www.joe.org].

Cushway B. 2002. Manajemen Sumber Daya Manusia (Perencanaan, Analisis, Kinerja, Penghargaan). Jakarta : PT. Elex Media Komputindo Kelompok Gramedia.

Departemen Dalam Negeri. 1990. Instruksi Menteri Dalam Negeri No. 9 Tahun 1990. Tentang Peningkatan Pembinaan mutu Pos Pelayanan Terpadu (Posyandu). Jakarta

Fabusoro E, Awotunde JA, Sodiya CI, Alarima CI. 2008. Status of Job Motivation and Job Performance of Field Level Extension Agents in Ogun State: Implications for Agricultural Development. Journal of Agricultural Education and Extension. 14(2): 139-152. [Internet]. [dapat 
diunduh dari: http://www.eric.ed. gov]

Gregson S, Liversey F. 1986. Management and the Organization. London ELBS/Heineman.

Havigurst dan Robert J. 1972. Development task and Eduction. 3 rd Ed. New York: David McKay Inc.

Heru AS. 2005. Kader Kesehatan Masyarakat. Jakarta (ID): EGC.

K-STATE. 2006. Confidential Document: Annual Extension Agent Performance Review. Kansas State University Agricultural Experiment Station and Cooperative Extension Service. [Internet]. [dapat diunduh dari: http://intranet.oznet.ksu. edu].

Lindner JR, Dooley KE. 2002. Agricultural Education Competencies and Progress towards a Doctoral Degree. Journal of Agricultural Education. 43(1): 57-68. [Internet]. [dapat diunduh dari: http://digilib.unsri.ac.id].

Long JL, Swortzel KA. 2007. Factors influencing individual job performance of Extension agents in the Mississippi State University Extension Service. Proceedings of the American Association for Agricultural Education. 34: 2940. [Internet]. [dapat diunduh dari: http://aged. caf.wvu.edu].

Mangkunegara AAP. 2000. Manajemen Sumber Daya Manusia. Perusahaan. Bandung (ID) : Remaja Rosda Karya.

Mastuti T. 2003. Studi uji Hubungan Beberapa Faktor Kader yang Berhubungan dengan Kelansungan kader Posyandu di Kecamatan Kecamatan Panjatan Kabupaten Kulon Progo Propinsi Daerah Istimewa Yogyakarta. [Internet]. [dapat diunduh dari: http://eprints.undip.ac.id].

Mathis RL, Jackson JH. 2002. Human Resource Management. Alih Bahasa. Jakarta (ID): Salemba Empat.

McCaslin NL, Mwangi J. 1994. Job Satisfaction of Kenya's Rift Valley Extension Agents. 32(3). [Internet]. [dapat diunduh dari: http://www.joe. org/joe].

Odugbesan, A. O. 1985. Motivation: A management tool. Perman Journal, 12 (1), 13 - 14

Oloruntoba A, Ajayi MT. 2003. Motivational Factors and Employees' Job Satisfaction in Large-Scale Private Farms in Ogun State, Nigeria. 10(1). [Internet]. [dapat diunduh dari: http://www. aiaee.org].
Puspasari A. 2002. Faktor-faktor yang Mempengaruhi Kinerja Kader Posyandu di Kota Sabang Propinsi Nanggroe Aceh Darussalam. [Skripsi]. Bogor (ID): Jurusan Gizi Masyarakat Dan Sumberdaya Keluarga, Fakultas Pertanian Institut Pertanian Bogor.

Rivai V. 2004. Manajemen Sumberdaya Manusia untuk Perusahaan. Jakarta (ID): Raja Grafindo Persada.

Rohmani S.A. 2001. Kinerja Penyuluh Pertanian dalam Pelaksanaan Tugas Pokoknya. [tesis]. Bogor (ID): Program Pascasarjana. Institut Pertanian Bogor.

Sahrul. 2006. Studi Tentang Faktor-Faktor yang Berhubungan dengan Kinerja Kader Posyandu di Wilayah Kerja Puskesmas Pompanua Kecamatan Ajangale Kabupaten Bone Tahun. Laporan Penelitian.

Suhanda NS, Jahi A, Sugihen BG, Susanto D. 2008. Job Performance of Agricultural Extension Agent in West Java Province. Jurnal Penyuluhan 4(2). [Internet]. [dapat diunduh dari: http:// journal.ipb.ac.id].

Syafrida A. 2003. Analisis Keaktifan Kader dalam Memberikan Pelayanan untuk Revitalisasi Posyandu di Kecamatan Dewantara Kabupaten Aceh Utara Tahun 2003. Medan (ID): Program Pascasarjana Universitas Sumatera Utara.

Terry BD, Israel GD. 2004. Agent Performance and Customer Satisfaction. Journal of Extension, Dec 2004. 42(6). [Internet]. [dapat diunduh dari: http://www.joe.org].

Thach LN, Ismail M, Uli J, Idris K. 2007. Individual Factors as Predictors of Extension Agents' Performance in Mekong Delta, Vietnam. The Journal of Human Resource and Adult Learning. 3(1). [Internet]. [dapat diunduh dari: http:// hraljournal.com].

The Texas A, M University System. 2005. Performance Appraisal System Extension Agent: 2005 Performance Summary. Texas Cooperative Extension. [Internet]. [dapat diunduh dari: http://countyprograms.tamu.edu]. Van den Ban AW, Hawkins HS. 1988. Agricultural Extension. New York: Longman Scientific \& Technical.

Vitriah M. 2010. Determinan Kinerja Kader Posyandu dalam Menuju Revitalisasi Posyandu di Kecamatan Pantai Labu Kabupaten Deli 
Jurnal Penyuluhan, Maret 2014 Vol. 10 No. 1

Serdang Tahun 2009. [tesis]. [Internet]. [dapat diunduh dari: http://repository.usu.ac.id]. 